\title{
Constraints Related to the Integration of the Information and Communication Technologies for Secondary Learners in the Learning of Physical Sciences in Morocco
}

OussamaDardary $^{1 *}$, Zineb Azar ${ }^{2}$, Malika Tridane ${ }^{3}$, Said Belaaouad ${ }^{4}$

1,2,3,4 Laboratory of Physical Chemistry of Materials LPCM, Ben M'Sik Faculty of Sciences

Hassan II University of Casablanca, Morocco

${ }^{2}$ Regional Center for Education and Training Casablanca Anfa Bd Bir Anzarane Casablanca, Morocco

dardaryosama@gmail.com

ABSTRACT: This study examines the degree of mastery and use of information and communication technologies (ICTs) by learners in high school sciences learning in the Casablanca - Settat region (Morocco). The research results made it possible to remember that there are still problems in the use of digital tools and the internet. As a result, obstacles to the pedagogical integration of ICTs into teaching practices oppose the progress of the education system. In order to push learners towards successful integration, several obstacles will be mentioned in this study, which must be taken into consideration in future attempts.

Keywords: ICT, Physics and Chemistry Sciences, Integration, Challenge, Morocco

Received: 19 May 2019, Revised 24 July 2019, Accepted 5 September 2019

DOI: $10.6025 / \mathrm{jdp} / 2019 / 9 / 4 / 117-126$

(C) 2019 DLINE. All Rights Reserved

\section{Introduction}

Following the accelerated pace and the growing importance of ICTs in the digital civilization, a development of a training program for some professors is necessary to initiate new training requirements (Genie (1)), strategies and role devolution between teachers and students. ICT techniques are very valuable to the foundation of education since it is the next revelation and game changer in the education system (2). With the use of ICTs, new forms of sharing appear, Electronic exchanges (emails, documents, lessons ...), rapid access to information, with the resulting time savings, favor a rapid speed of electronic exchanges (3). However, the use of ICTs is still modest (Bibeau, 2005), which makes it possible to push the responsible (government ministry) to act as quickly as possible, in order to develop an effective strategy of continuous training, pedagogical accompaniment and supports according to the needs of teachers and learners, in order to help them adapt to the change in our modes of learning (4). 
The development of student learning has long been a fundamental objective of government information and communication technology policies in the various countries of the Organization for Economic Co-operation and Development (OECD). However, the speed of diffusion of these technologies varies from one country to another depending on gross domestic products, investments and the size of the country (5) (FDA Report 2010) (6).

The Higher Education Council (7) declares in 2008 that the French National Education must push future citizens towards the integration of ICTs in their society (8). It is important to understand that this is no longer a choice for the learner but an obligation, in order to continue the global race towards new technologies.

To this end, the 2nd World Congress of Open Educational Resources (OER)(9) held in Ljubljana capital of Slovenia in September 2017, invites the international community to participate in public action to monitor the progress of countries on the road to digital inclusion, «OERs for Inclusive and Equitable Quality Education: From Commitment to Action», reflecting the role that OERs can play in order to achieve the Development Agenda sustainable development by 2030 and above all Sustainable Development Goal 4 (SDG 4) on quality of education, the teacher must prepare himself better in the learning process, Therefore teachers and student must prepare themselves better in the teaching-learning process to deal with ICTs (10).

The objective of our work is to highlight the difficulties, failures and successes of the integration of the digital age in the teaching of the physical and chemical sciences (PCS) in Morocco at the high school and the middle school. Our study is based on the analysis of the responses of 805 learners to a questionnaire that we submitted to them.

\section{Research Questions}

This study aims on the one hand to identify the obstacles and the constraints of the integration of the TICs in the teaching of the physical and chemical sciences in Morocco, and on the other hand to study the current state of the control of the learners of the computer tools. We propose to answer to three specific questions for this research:

-What is the place of the digital age in the teaching-learning operation of the physical and chemical sciences in middle school and high school in Morocco?

- What are the constraints of integrating the digital tools into the teaching-learning operation of the physical and chemical sciences and how to overcome them?

- What are the main barriers to the use and control of ICTs by learners?

\section{Context}

The National Charter of Education and Training (Ministry of National Education in Morocco, 1999), in article 10, encourages the integration of ICTs in education by teachers, and promotes the creation of computer rooms in every school in Moroccan territory with a view of paving the way for distance education and learning, also it encourage all teachers to create their own digital resources.

Morocco, like most countries in the world, is following the path towards the diffusion of new technologies, in all public schools, in order to improve the quality of the educational offer. The National Charter of Education has supported the need for the integration of ICT for the first time in October 1999.

In this work, we aim to reveal all the barriers behind the lack of the use of ICTs by the physical and chemical teachers of the secondary education, that have been reported in previous studies (Alj \& Benjelloun 2013; Ouardaoui et al, 2012).

\section{Methodology}

To carry out this study, a survey was conducted in middle and high public schools in the region of Casablanca - Settat (Morocco), exactly in the provincial direction of MoulayRachid-Sidi Othman, during the school year 2016/2017.

The target population for our study is 805 secondary school students, 450 middle school students and 355 high school students.

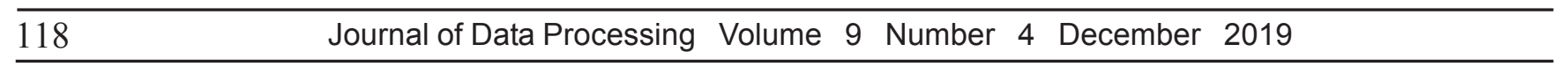


To collect information on constraints related to the successful integration of ICTs in physics and chemistry PC sciences, we used a questionnaire as an investigative tool. Questionnaires were distributed in 21 institutions: 12 middle schools and 9 high schools, it contains 24 questions addressed to the learners, some of which are closed and the others are open.

\subsection{The Questionnaire}

The data collection was carried out by means of an anonymous questionnaire, all 24 questions aimed at clear answers on the fundamental axes of the survey:

- Personal information: Age, school level ...

- Possession of a digital tool;

- Degree of mastery of this tool;

- Internet access and use of the internet;

- Importance of ICTs use in the classroom and at home;

- The conditions of ICTs use, according to the learners;

- Training of ICTs learners;

- Participation of learners in the use of ICTs in the classroom;

\subsection{Results and Discussion}

The data collected from the questionnaires, the interviews and the information accumulated during our investigation are classified and entered in the form of tables and graphs. The processing was done by SPSS Statistics 20 and Microsoft Excel.

\subsection{Profiles of our Population}

- The Dominant Gender of our Population

$44.10 \%$ of our population are males, while $55.40 \%$ are females.

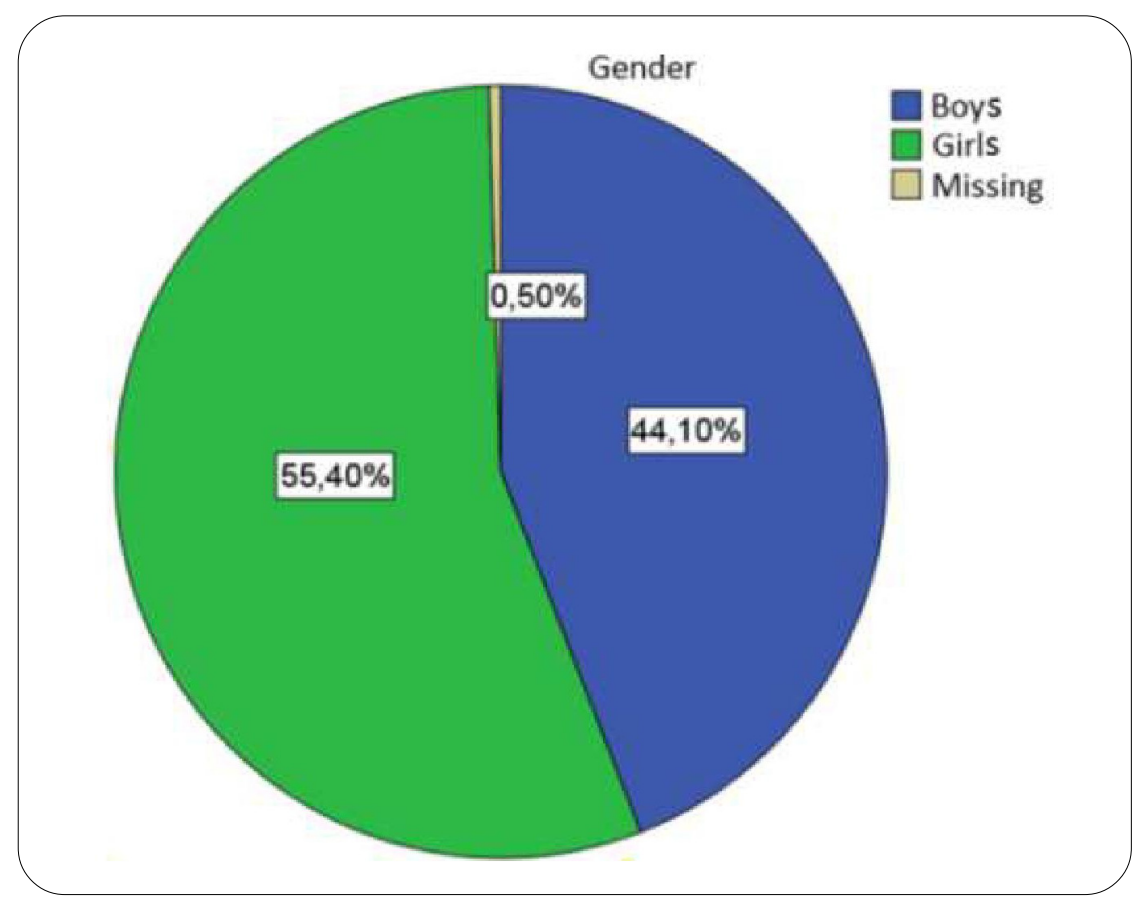

Figure 1. The distribution of learners by gender 
- Age range of our Population

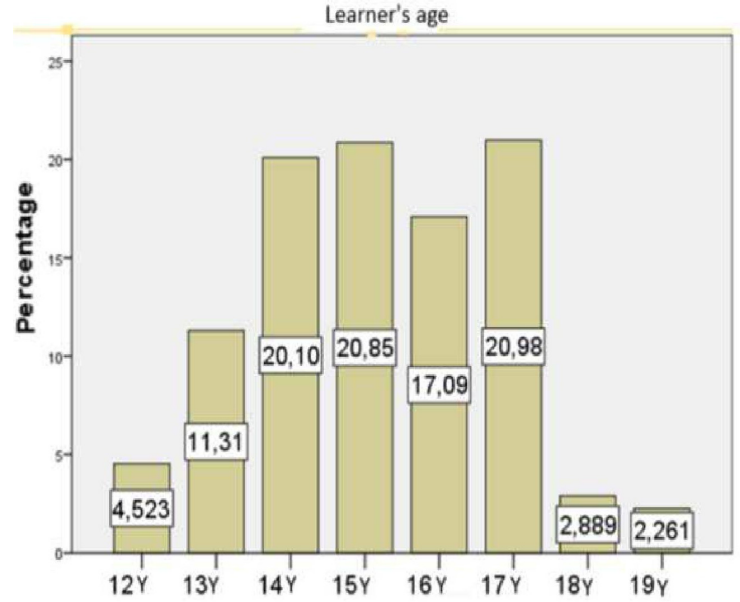

Figure 2. The distribution of learners by age

\section{- Possession of a Computer or Tablet}

The results showed that (78.9\%) of learners have a computer or tablet at home. $(38.5 \%)$ of the students surveyed said that their parents allow them to use the computer or tablet every day (see Figure 3 ).

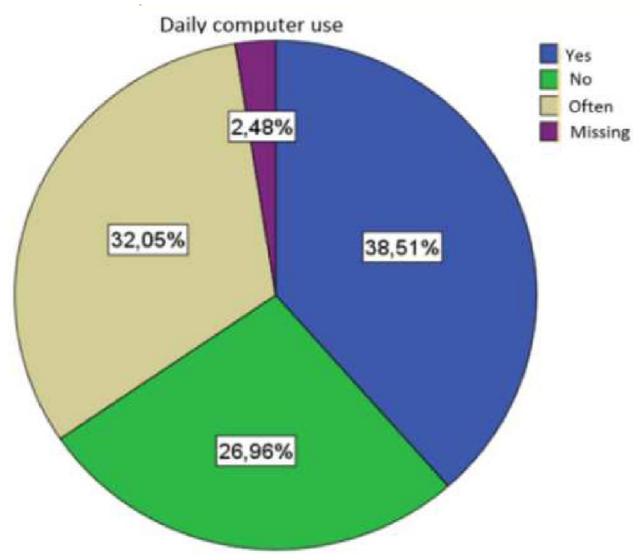

Figure 3. Parental permission for daily computer use

$(86.3 \%)$ of learners have access to the internet, here is a Figure 4 below that shows the places of access to the internet.

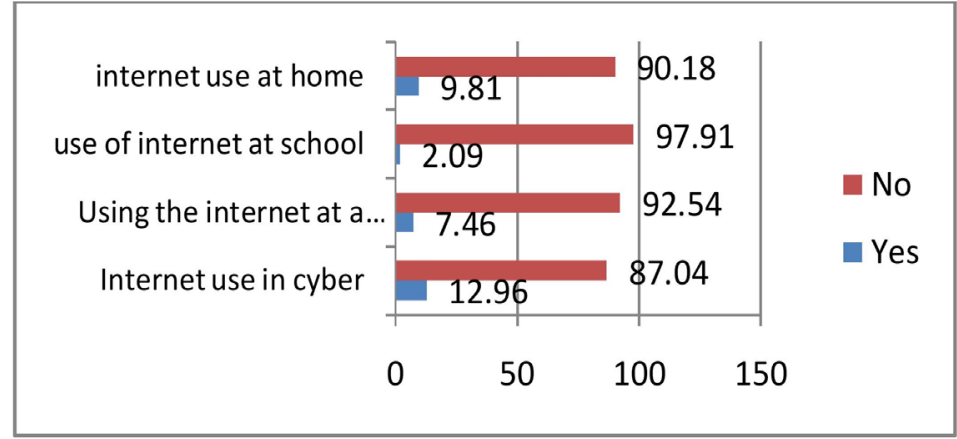

Figure 4. Places of access to the internet 


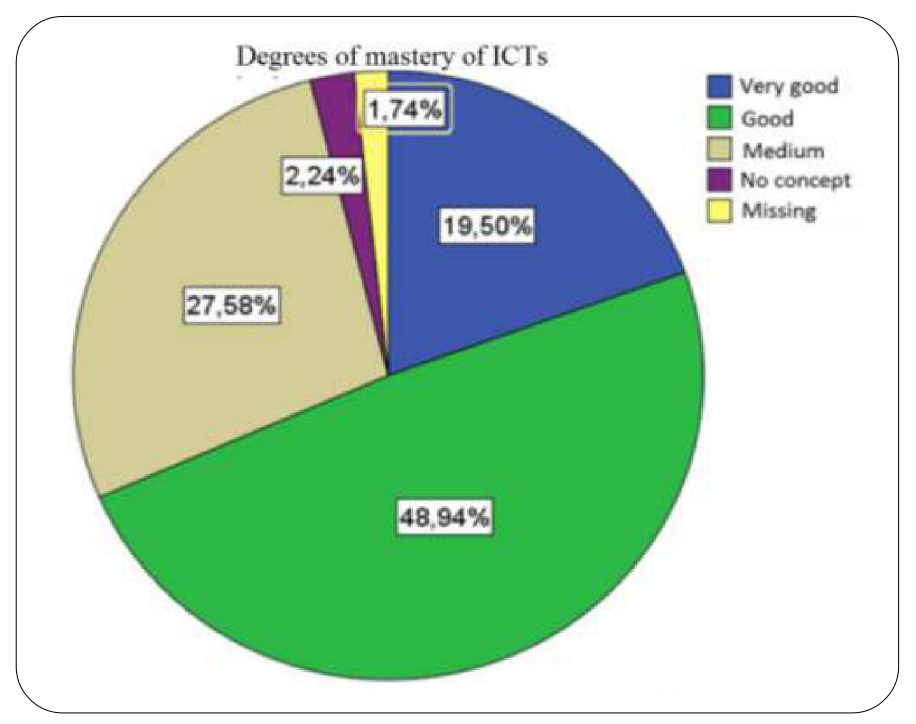

Figure 5. Degrees of mastery of ICTs by learners

\subsection{Personal use of ICTs by Learners}

For those who use the computer daily, Figure 6 below shows how much time learners spend in front of their computers each day.

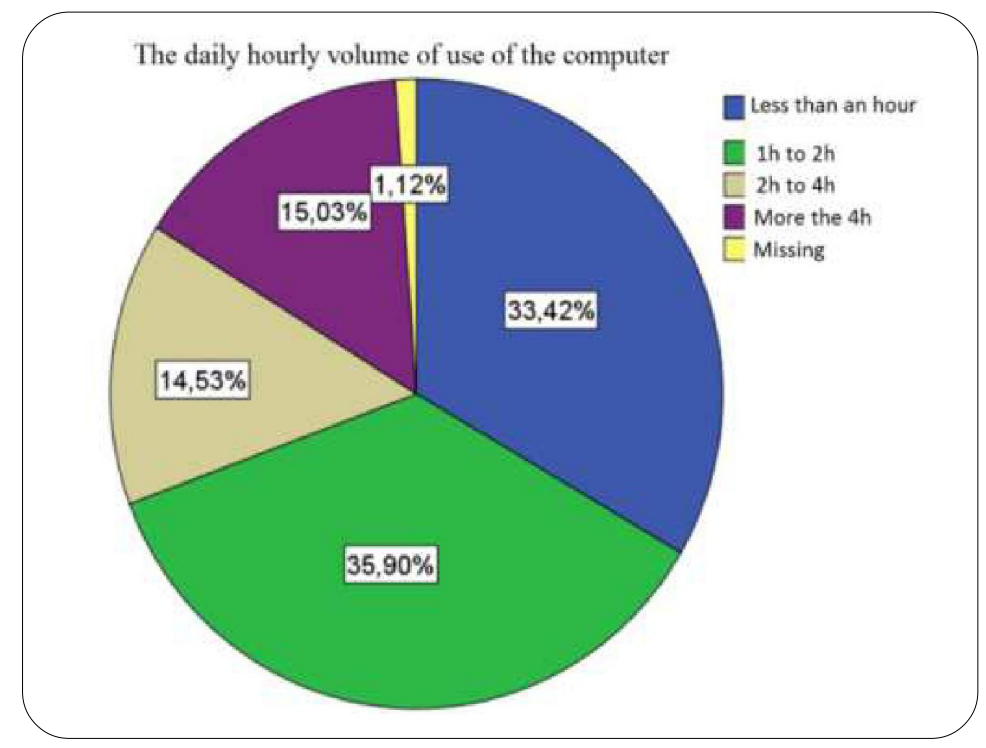

Figure 6. The daily hourly volume of use of the computer

The data collected showed that ( $88.7 \%$ ) of the learners questioned (those who have a computer) use the computer for homework (apprenticeship). The table below shows the frequency of its use for the different daily activities. Security and protection must be applied, in all classrooms and outside schools, a national study was conducted in July 2016 by the opinion poll firm "Averty" with "Kaspersky Lab" $(11,12)$ shows that the majority of parents surveyed indicate that their children use the web daily according to different rhythms:

- Lessthan an hour (30.7\%);

- $1 \mathrm{~h}$ to $2 \mathrm{~h}(23 \%)$;

- $2 \mathrm{~h}$ to $4 \mathrm{~h}(17 \%)$; 
- More than 4 hours (16.6\%);

• No information (7.1\%).

\begin{tabular}{|l|l|l|l|l|}
\hline Activity & Regularly & Often & Rarely & I do not use \\
\hline Exercise & $19,40 \%$ & $49,40 \%$ & $13,60 \%$ & $17,60 \%$ \\
\hline Research & $45,90 \%$ & $40 \%$ & $5,90 \%$ & $8,10 \%$ \\
\hline Translation & $21,80 \%$ & $40 \%$ & $19,90 \%$ & $18,20 \%$ \\
\hline Revision & $23 \%$ & $39 \%$ & $18,20 \%$ & $19,90 \%$ \\
\hline Preparation of presentations & $27,70 \%$ & $31 \%$ & $18,90 \%$ & $22,40 \%$ \\
\hline Information exchange & $27,40 \%$ & $31,90 \%$ & $16,70 \%$ & $24 \%$ \\
\hline $\begin{array}{l}\text { Improve language by movies, } \\
\text { animated, series ... }\end{array}$ & $27,70 \%$ & 31,10 & $17,20 \%$ & $24,10 \%$ \\
\hline Watch scientific experiments & $19,30 \%$ & $39,50 \%$ & $22,50 \%$ & $18,70 \%$ \\
\hline
\end{tabular}

Table 1. Types of ICTs use by learners

ICT use can be helpful in preparing educational contents (13). Most learners (71.6\%) reported having the pleasure of using ICTs.

\subsection{Use of ICTs by Teachers}

$(40 \%)$ of the learners surveyed said that their physical chemical PC science teachers use ICTs in classroom with them, "(45\%) in other study made for teachers" (14). See Fig 7 below:

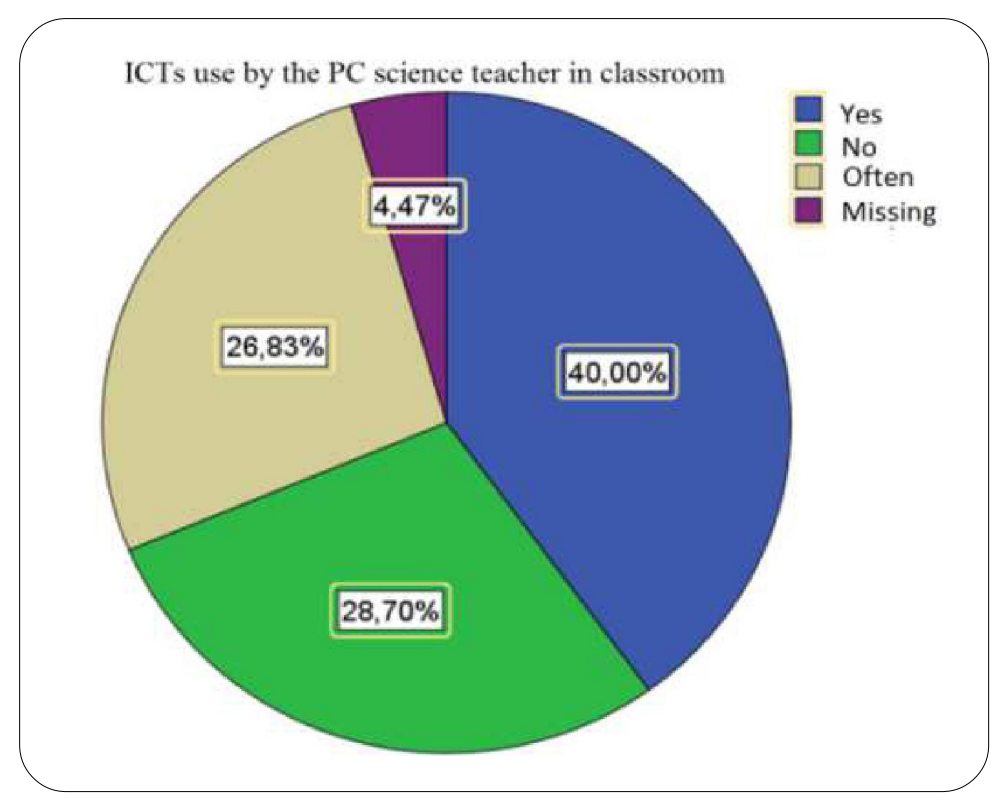

Figure 7. ICTs use by the physics and chemistry PC sciences teachers in classroom

For teachers who use ICTs with their students, Fig 8 below shows the field of their uses (course - experience - simulation), according to the learners: 


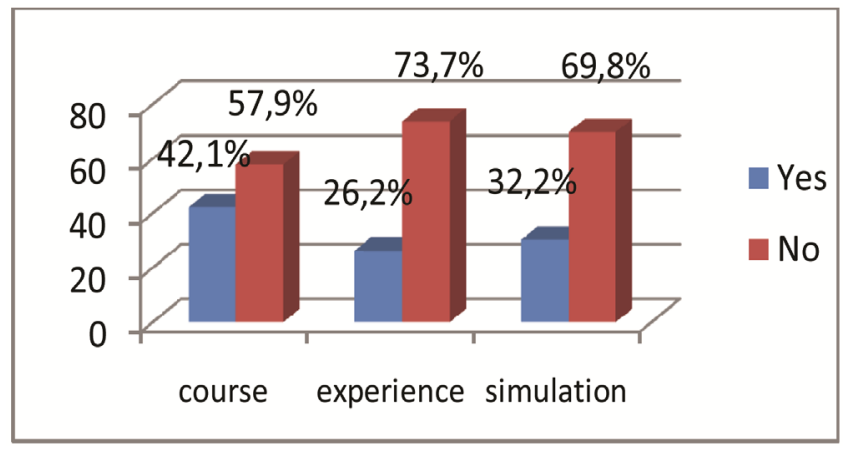

Figure 8. Field of ICTs use by the physics and chemistry PC sciences teachers

\begin{tabular}{|l|l|l|l|c|}
\hline ICT tool & Regularly & Often & Rarely & I do not use \\
\hline Video projector & $33,4 \%$ & $15,8 \%$ & $8,8 \%$ & $41,9 \%$ \\
\hline Educational programs & $7,8 \%$ & $23,2 \%$ & $12,4 \%$ & $56,6 \%$ \\
\hline Computer-assisted experience (CAEx) & $11,5 \%$ & $16,9 \%$ & $10,7 \%$ & $60,8 \%$ \\
\hline Interactive white board & $10,6 \%$ & $7,2 \%$ & $8,3 \%$ & $74 \%$ \\
\hline TV and DVD player & $3,4 \%$ & $9,5 \%$ & $11,4 \%$ & $75,4 \%$ \\
\hline Computer interface & $6,2 \%$ & $11,7 \%$ & $12,5 \%$ & $69,5 \%$ \\
\hline
\end{tabular}

Table 2. Percentage of Types of ICT Use by the physics and chemistry PC sciences Teachers

The majority of learners (62\%) indicated that they prefer their physics and chemistry PC sciences teacher to use ICTs regularly with them (Figure 9).

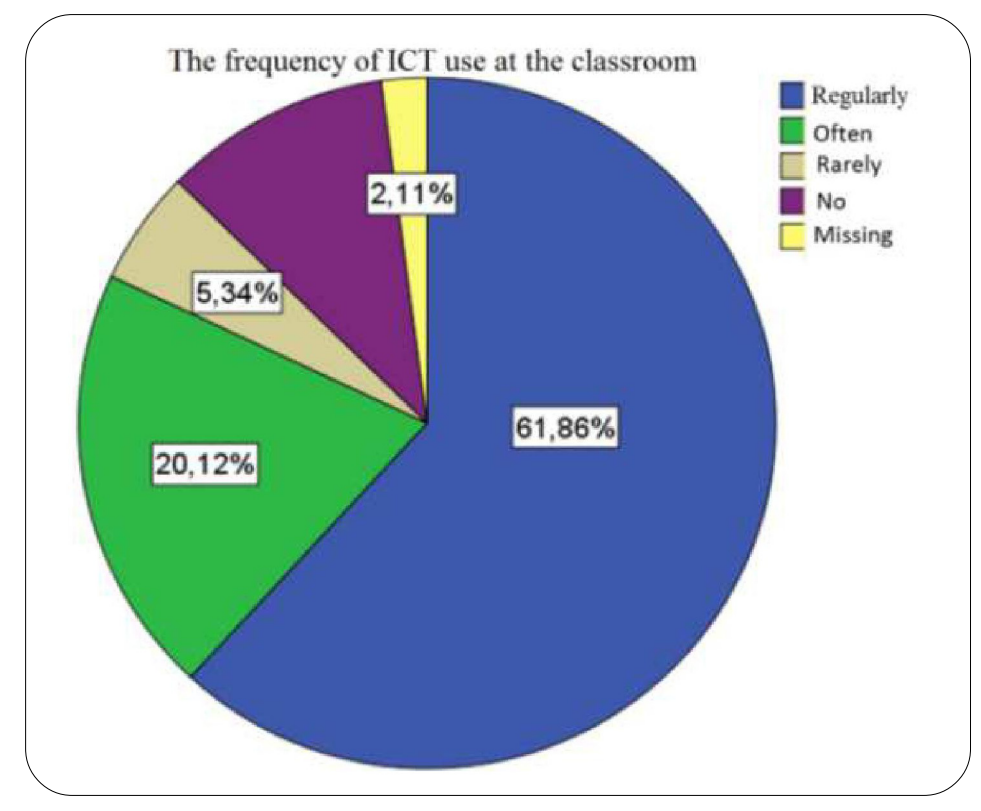

Figure 9. The frequency of ICTs use at the classroom desired by learners 
Most learners (67.2\%) indicated that they did not participate in the use of ICTs by teachers, and (79.25\%) said that they really prefer to participate.

The involvement of learners in the use of ICTs is very important for learning, «Tell me and I will forget it; Teach it to me and I will remember it; Involve me and I will learn. »- Benjamin Franklin.

In addition, approximately (83.9\%) of learners prefer the learning method that uses ICTs for multiple reasons. It is:Modern (7\%), Clear (11\%), Simple (8\%), Fast (10\%), Fun (3\%) and Easy to use (13\%).

\subsection{Barriers Related to ICTs Integration by Learners}

Among the constraints related to the successful integration of information and communication technologies into the teaching of the physical and chemical sciences is the insufficiency of the minimum weekly volume of ICTs use for each student, depending on the grade level. This hourly volume can be summarized as follows:

\begin{tabular}{|l|l|l|l|}
\hline Level & Primary & Middle school & High school \\
\hline Minimum weekly hours & 1 HOUR & 2 HOURS & 3 HOURS \\
\hline
\end{tabular}

Table 3. Minimum Weekly Volume of ICTs Use for each student (8)

Among these constraints, there are also:

- Lack of multimedia rooms in targeted institutions.

- Lack of computer training, which is limited to the first year of the high school grade.

Some obstacles are due to the management and distribution of didactic material, extracted from the reports of the two inspections the Ministry's general objectives, which are aimed primarily at setting the conditions for good governance in the management of the didactic materials file with regard to the stages of its acquisition and its use, and following the general observations made by the magistrates of the Court of Auditors concerning this subject (15), namely:

- The lack of precision during the identification of the equipment requirements that are the object of acquisition operations;

- Non-compliance with the regulatory provisions governing public procurement, particularly those governing the preparation of CPS;

- Non-compliance with the regulatory provisions governing the preparation and award of public contracts for the acquisition of teaching materials;

- The failure of the supervisory, monitoring and control function required when the academies receive the material;

- The distribution and delivery to schools of equipment that does not comply with the technical specifications of the CPS;

- Non-compliance with the rules of public property management: poor record keeping

- Non-compliance with the rules governing the management, storage and use of products.

Research has also discovered that incompatible power supply and poor network connectivity are the main constraints for utilization of ICTs (16).

\subsection{The Levers to allow the use of ICTs by Learners}

ICT promote more in-depth learning among students, as well as its integration has a positive impact on learning and metacognition. ICTs have several impacts on learners (17). The ICT era encourages the student for active participation. They write, listen or speak to have a touch with online platforms. This kind of communication helps them to learn and understand easily in good level. Wide range of reading and writing is the essential thing for literary or scientific learning (18).Among the levers for using ICTs by learners, it is necessary to:

124 Journal of Data Processing Volume 9 Number 4 December 2019


- Install multimedia rooms or equip existing multimedia rooms;

- Increase the number of weekly computer sessions;

- Train learners as they learn other school subjects (in parallel);

-Encourage learners to use ICTs through presentations, research, etc.

- Involve learners in the different activities that contain ICTs;

- Provide teachers with a complete training;

\section{Conclusion}

The analysis of the results revealed that among the main constraints that impede the integration of ICTs by students in middle and high schools in the region of Casablanca - Settat, MoulayRachid - Sidi Othman Provincial Direction:

- Lack of home computer access (61.5\%);

- Time of access to the computer by students at school is limited;

- Lack of access to the internet (13.7\%);

- Lack of computer training (70.4\%);

- Absence of oriented use (research activities, exercises, courses, ..), and secured use (protection against malicious sites) of computers;

- Lack of will for ICTs (28.4\%);

- Lack of participation in activities containing ICTs (32.8\%);

- Lack of ICTs use by teachers $(28.7 \%)$;

In order to ensure a better integration of ICTs in the Moroccan education system, the Ministry of Education and Teaching and the teachers must:

- Install multimedia rooms or equip existing multimedia rooms;

- Increase the number of weekly computer sessions;

- Encourage learners to use ICTs through presentations, research, etc.

- Involve learners in the different activities that contain ICTs;

So before putting in place any attempts to generalize innovative practices in teaching, the Ministry of Education and Teaching must take into consideration several obstacles that were highlighted during our field study.

Finally, all the learners surveyed demand to involve them and encourage them to use the new information and communication technologies. All the physics and chemistry PC sciences teachers require the presence of the open educational resources (OER) available in the manual in digital form and their organization consistent with the program under study.

\section{List of Abbreviations}

ICTs : Information and communication technologies.

FDA : French Development Agency.

PCS : Physical and chemical science.

OER : open educational resources.

\section{Conflicts of Interest}

The authors declare that they have no conflicts of interest. 


\section{References}

[1] Generalization of Information and Communication Technologies, Morocco, Moroccan Ministry of Education, 2006.

[2] Adarsh, S., Kumar, Akhila, S., Anil, Bhanupriya, L, H., Jyothilakshmy. (2018). ICT learning and its butterfly effects on students' academic performance, International Journal of Engineering \& Technology, 7 (3.29) 373-375, 3.

[3] Mohamed AchrafNafzaoui, AbdellahSebbar, AbdelazizBerdi. (2019). Information and Communication Technologies (ICT), At the Service of Knowledge Sharing in Organizations: Case of the Moroccan Banking Sector, International Journal of Engineering \& Technology, 8 (1.11) 84-87, 3 .

[4] El Ouidadi Omar. (2011). Analysis of attitudes and needs of Moroccan teachers in ICT: Case of the academy (RAEF) of FESBoulemane, Morocco, Radisma, 7, 4-6.

[5] El Ouidadi Omar. (2013). Main factors influencing the use of ICT in Moroccan teachers, frantice.net, (January) (6).

[6] French Development Agency, Paris, French, 1998, 2-3.

[7] Higher Council of Education, French, 1989, 2.

[8] ADIL EL MADHI. (2011). The program GENIE stakes and reality, the pedagogical integration of the TICE-Faculty of Arts and Humanities, Kenitra, 2011, 138.

[9] Open educational resources, Ljubljana, Slovenia, 2017, September, 5-8.

[10] Saripudin, S., Sumarto, S., Juanda, E. A., Ade Ghafar Abdullah, Ana, A. (2018). Understanding Technology Literacy: The Characteristics of ICT Literacy Vocational Teachers, International Journal of Engineering \& Technology, 7 (4.33) 182-185, 1.

[11] L'Autorité Nationale de Réglementation des Télécommunications. www.bladi.net/maroc-abonnes-internet-3g,40002.html

[12] Oussama Dardary. (2018). Bibliographic Study on Child Protection Software for the Internet, IOSR Journal of Research \& Method in Education (IOSR-JRME, 8(4) Ver. III (July - August 2018), 15-20.

[13] JungHoon Kim. (2016). Analysis of the Degree to which ICT use by College Students in Departments of Radiology has on their Learning, Indian Journal of Science and Technology, 9(24), (June), DOI: 10.17485/ijst/2016/v9i24/96056

[14] Oussama Dardary, Malika Tridane., Said Belaaouad. (2018). Constraints Related to the Integration of Information and Communication Technologies in the Teaching of the Physical Sciences at the Level of the Moroccan Educational System, Indian Journal of Science and Technology, 11(44), (November). DOI: 10.17485/ijst/2018/v11i44/132138

[15] Report N2 of the Court of Auditors (Didactic Materials), The approach of the implementation of the recommendations of the Court of Auditors and the proposals of the two general inspections of the Ministry concerning the management of the didactic materials and chemicals. 2017 (3).

[16] Nadzifah Yaakub, AmirulArif Bin Ab Aziz., Fazleen Abdul Fatah. (2018). Evaluation on Accessibility and Usage of Information and Communication Technology (ICT): Insights from Smallholders in Johor, Malaysia, International Journal of Engineering \& Technology, 7 (4.43), 1-5.

[17] Oubibi Mohamed, Zhao Wei. (2018). The Role of ICT in Learning Process of International Student at Chinese University, International Journal of Engineering \& Technology, 7 (4.32) 97-100 (2).

[18] Mohankumar, S., Vijayalakshmi, V., Manjusha, C. B. (2018). The Effectiveness of Ict in Edifying Language Learning: a Quasi -Experimental Study, International Journal of Engineering \& Technology, 7 (3.34) 527-529 (1). 